IRA-International Journal of Education \&

Multidisciplinary Studies

QUARTERLY

ISSN 2455-2526; Vol.16, Issue 03 (July-Sep, 2020)

Pg. no. 171-180.

Institute of Research Advances

https://research-advances.org/index.php/IJEMS

IIRA

\title{
Song of Chinese American Females- A Traumatic Reading of The Woman Warrior
}

\section{Zhao Qing}

Department of Foreign Languages, Harbin Engineering University, PRC China.

Type of Work: Peer-Reviewed

DOl: http://dx.doi.org/10.21013/jems.v16.n3.p6

\section{How to cite this paper:}

Qing, Z. (2020). Song of Chinese American Females- A Traumatic Reading of The Woman Warrior. IRA International Journal of Education and Multidisciplinary Studies (ISSN 2455-2526), 16(3), 171-180. DOl: http://dx.doi.org/10.21013/jems.v16.n3.p6

(C) Institute of Research Advances.

This work is licensed under a Creative Commons Attribution-NonCommercial 4.0 International License subject to a proper citation to the publication source of the work.

Disclaimer: The scholarly papers as reviewed and published by the Institute of Research Advances (IRA) are the views and opinions of their respective authors and are not the views or opinions of the IRA. The IRA disclaims of any harm or loss caused due to the published content to any party.

Institute of Research Advances is an institutional publisher member of Publishers International Linking Association Inc. (PILA-CrossRef), USA. The institute is an institutional signatory to the Budapest Open Access Initiative, Hungary advocating the open-access of scientific and scholarly knowledge. The Institute is a registered content provider under Open Access Initiative Protocol for Metadata Harvesting (OAI-PMH).

The journal is indexed \& included in WorldCat Discovery Service (USA), CrossRef Metadata Search (USA), WorldCat (USA), OCLC (USA), Open J-Gate (India), EZB (Germany) Scilit (Switzerland), Airiti (China), Bielefeld Academic Search Engine (BASE) of Bielefeld University, Germany, PKP Index of Simon Fraser University, Canada. 


\section{ABSTRACT}

Maxine Hong Kingston is a famous Chinese American writer, who is adept at interpreting the living conditions of Chinese American immigrants by making vivid and profound description. She writes several influential novels and the publication of her masterpiece The Woman Warrior makes her immediately renowned in the American literary circle. This paper is going to apply trauma theory to describe the Chinese females' miserable fates, to further explore the causes of their trauma, and to focus on how they treat trauma, overcome trauma and become "woman warriors".

Keywords: The Woman Warrior; trauma theory; Chinese American females

\section{Introduction}

Maxine Hong Kingston was born on October 27, 1946, in California. She is a distinguished Chinese American novelist, whose ancestral home is Xin Hui in Guangdong Province. Her family lives in Stockton and her parents run a laundry workshop for a living. Although the material of her family is scared, the spiritual world of the children is very rich. As a traditional intellectual, Kingston's father uses his own profound literary cultivation to influence her gradually. As for her mother Zhu Lanying, she is a master of storytelling. So Kingston is greatly influenced by Chinese culture. In one sense, she understands the goodness, evil, beauty, and ugliness in Chinese stories in her unique way. Moreover, she is obsessed with vivid legends and splendid fairy tales, slowly developing a keen interest in literature. She graduated from Berkeley University in 1962. Then she and her family moved to Hawaii and began to teach English at Berkeley University in California.

Being widely regarded as one of the representative female writers during the flourishing period of American Chinese literature, Kingston has earned numerous awards: the National Book Award, the National Book Critics Award for Nonfiction, the PEN West Award for Fiction, and so forth. Most of her novels are based on the stories told by her mother about the Chinese myth, traditional culture, and ancient legends. "Among all her works, The Woman Warrior: Memoirs of a Girlhood Among Ghost is the most influential and famous novel which led the American Chinese literature to a new peak". ${ }^{[1] 56}$ The Woman Warrior is based on Chinese stories, depicting the Chinese American females' frustration and struggle in America and the different attitude they take towards trauma that results in their different fates. Kingston wrote this novel from the perspective of Chinese immigrants and revealed the living conditions and psychological impact of them.

The Woman Warrior includes five chapters: No Name Woman, White Tigers, Shaman, At the Western Palace, A Song for a Barbarian Reed Pipe. Seemingly, there is not a distinct connection between these five chapters. In reality, they are closely connected with each other, thus organizing all materials as a whole. In chapter one, it describes the miserable destiny of No Name Woman who commits suicide because she gets pregnant after her husband has immigrated to America. The repression of patriarchy results in No Name aunt's physical and mental trauma. In chapter two, the author vividly represents a fantasy world in which Maxine becomes a real heroine possessing outstanding wisdom and talent who can protect her family and herself with supernatural power. In chapter three "Shaman", Kingston illustrates the experience that Brave Orchid makes great effort to become a country doctor, a respectable and noble vocation in China. However, after coming to America, she receives unfair treatment as a Chinese American female because of racial discrimination. 
In chapter four, it narrates Moon Orchid who lived in China alone for thirty years. To her great surprise, her husband has had a new wife in America. Under such an unfair circumstance, Moon Orchid didn't have the courage to get her own rights and interests back. It is virtually inevitable that weak and paralyzed Moon Orchid suffers serious mental disease and finally collapses, spending the rest of her life in a mental hospital in California. In chapter five, Kingston describes the process she struggles to overcome the language barrier and breaks "silence". In the end, she finds the spiritual strength in her inner world to become a real "woman warrior".

As a classic work, The Woman Warrior has an enduring charm that is able to survive the passage of time. Many critics have probed deeply into it. Some analyze the female images to expose the state of the Chinese ethnic group's life. Some investigate the establishment of the identity of Chinese American females. Some explore the basic relationship among women-the mother-daughter relationship to discuss the different causes of females' trauma and the possibility of recovery. "The rise of trauma theory has provided novelists with new ways of trauma and has shifted attention away from the question of what is remembered of the past and why it is remembered." ${ }^{[2] 3}$. Therefore, this thesis enables people to study this work and other ethic literature from a new angle - trauma theory.

\section{Manifestations of the Trauma in the characters}

\subsection{The Traumatic experience of No Name Woman}

In the first section of The Woman Warrior, Maxine's mother, Brave Orchid, told her the story of No Name Woman. No Name aunt's pregnancy is a puzzle for all the people in the village. Only one supposition is reasonable: The No Name Woman is raped by an anonymous man, but she is forced and terrified into keeping the secret. The only thing she could do is to endure the misunderstanding and insults of the villagers and keep silent. "She always did as she was told." ${ }^{[3] 6}$. In traditional Chinese society, women were required to comply with the feudal Confucian ideas of "Three Obedience and Four Virtues". That's to say, women should be loyal to their husbands. ${ }^{[4] 27}$ So the No Name Woman dares not and cannot love and have a sexual affair with another man. According to the villagers' traditional concepts, adultery is a sin that is not forgiven. All people's reactions are ruthless and indifferent. The villagers insult and censure her for adultery. What upsets her most is her family's attitude: Her beloved family abandoned her after she delivered and even cursed her. "Ghost! Dead ghost! Ghost!" [3]14. She was even expelled from the house and erased from the family tree. In addition, Maxine's mother even thought No Name aunt's premarital pregnancy was the shame of the whole family and told her that domestic shame should not be published. One sentence in this chapter is very ironic: "Don't tell anyone you had an aunt. Your father does not want to hear the name. She has never been born". [3]19. All these unsympathetic responses exert an overwhelming impact on her - She is forced to drown herself in the family well with her newborn child out of helplessness and despair. "The real punishment was not the raid swiftly inflicted by the villagers, but the family's deliberately forgetting her." [3]20

In the patriarchal system, women are bound to be inferior to men. "Since the period of the Western Zhou Dynasty, the female was called Yin, and Yin usually means dark, cold and lifeless". ${ }^{[5] 112}$. On the contrary, the male was called Yang which means bright, warm, and thriving. Suffering from chronic 
sexual and mental disease, No Name Woman has lost the ability to resist and even to articulate. She knows that even if she tells the truth of her pregnancy and exposes the man, nobody would stand on her side and believe in her. No matter what she does and how she argues, the villagers would blame her for the sin. The reality is harsh. Nobody wishes to help her, let alone trust her. No matter how she struggles, the result is the same. Such a patriarchal society deprives her of the right to give a voice, so it is out of the question for No Name Woman to take such a lamentable consequence. Before No Name Woman died, she suffered from immense psychological trauma, which brought No Name Woman to the final mental collapse. "'They’ve hurt me too much', she thought. 'This is gall, and it will kill me." [3]18. So her suicide fully demonstrates the No Name Woman's utter despair with the world.

\subsection{The Traumatic Experience of Moon Orchid}

In the fourth chapter of The Woman Warrior, aunt Moon Orchid comes to America with the help of Maxine's mother, Brave Orchid. She has lived in China alone for thirty years, depending on the money sent by her husband every month. For Moon Orchid, only in that way could she live a comfortable and stable life. 'He's given me so much money. I've had all the food and clothes and servants I've wanted. And he's supported our daughter too, even though she's only a girl. He sent her to college." [3]111 When Brave Orchid encourages her to see her husband face to face, she hesitates and even dares not to defend the plan. "I can't bother him, I mustn't bother him". ${ }^{[3] 111}$

In the marital relationship, she always plays a submissive role, stands all the unfair treatment, and has little courage to resist. "Do you think he'll get angry at me because I came without telling him?" [3]111. When she heard her husband had had a new family in America, she even believed that he didn't abandon her. In the whole story, Moon Orchid is weak and cowardly. Actually, Moon Orchid could realize and acknowledge that she is wishy-washy. Moon Orchid is a representative of the Chinese traditional woman, who is willing to accept the arrangement made by others without any compliant. So she could not face the grim reality that her husband has started a new life in America and he tries to elude her. Until that time, all her beautiful fantasy vanishes like a bubble. Finally, the last wall of her mental world totally collapses because of the great sorrow and helplessness.

For one thing, the living expense of Moon Orchid is totally supported by her husband. So she is not economically independent, which is a barrier preventing her from starting a new life in America. For another thing, Moon Orchid is very lonely in America for she only has a few of her peers. She has not interpersonal communication in that she is not able to talk with others fluently in English. Having lost her dignity and confidence, Moon Orchid does not want to struggle anymore. It is clear that Moon Orchid's cowardice, ignorance, and cultural difference constrain her from adapting to American life. When she encounters these sudden traumatic events, she appears the symptom of anxiety, helplessness, fragility, and fear. Both the physical and mental trauma lead Moon Orchid into a desperate situation-She becomes mad in the end. Post-traumatic stress disorder attacked her again, resulting in the tragic end.

\subsection{The traumatic Experience of Maxine and Her classmates}

Maxine, as the second-generation immigrant, has to face the multiple challenges of the mainstream 
society, female identity, and cultural difference when her personality is still immature. All these challenges are undoubtedly arduous, which brings her deep internal trauma. In American society, the most obvious external manifestation of internal trauma is silence. "When I went to kindergarten and had to speak English for the first time, I become silent." ${ }^{[3] 145}$. Little Maxine cannot speak English smoothly and she is always laughed by white children. She dares not talk, and the silence almost occupies all her childhood. "A telephone call makes my throat bleed and takes up that day's courage. It spoils my day with self-disgust when I hear my broken voice come skittering out into the open. It makes people wince to hear it. ${ }^{\text {[3]164 }}$.In order to make Maxine own the better ability to use English and express herself in the mainstream society, Brave Orchid cut Maxine's frenum. "I cut it so that you would not be tongue-tied. Your tongue would be able to move in any language. You will be able to speak languages that are totally different from one another. You will be able to pronounce anything. Your frenum looked too tight to do those things, so I cut it." [3]145

Throughout the whole book, it is easy to find that Maxine's childhood is dark without any color and full of worries and a sense of being inferior. "Traumatic experience can inspire not only a loss of self-confidence but also a loss of courage in the social and cultural structures that are supposed to create safety.,"[6]13

In this strange and desperate situation, Maxine becomes more and more silent, using aphasia to avoid any human contact. Moreover, silence is collective. "A collective trauma is a traumatic psychological effect inflicted agony on a group of people sharing in common." [7]17. Her classmates often keep silent, too. The sense of inferiority comes from their identity as Chinese. "The other Chinese girls did not talk either, so I knew the silence had to do with being a Chinese girl." [3]147. This kind of emotional trauma evolves into a complex over time. These Chinese girls are deeply hurt by others' discrimination and mock. Thus, they don't have the courage and confidence to speak out, resulting in their collective aphasia. Apparently, the collective aphasia is the external manifestation of their collective trauma. According to Judith Herman, there are three stages necessary to recover from trauma. The central task of the first stage is establishing a sense of safety. "Survivors feel unsafe in their bodies. Their emotions and their thinking feel out of control. They also feel unsafe in their relation to other people. ${ }^{[8] 113}$. They refuse to talk with others and have a strong desire to protect themselves from the familiar and strange country.

\section{The Root Causes of Chinese Females' Trauma}

\subsection{Oppression of Patriarchy}

Since ancient times, women, as a special group, have always been oppressed by the patriarchal society. Especially in traditional China, the patriarchal system was widely prevalent-Confucianism promoted the legalization of the patriarchy and "the Three Obedience and Four Virtues". When a girl was born, her statue is doomed to be inferior to the male. For a long time, men have taken a dominant place in politics, economy, law, education, military, or family. Women, at the bottom of the patriarchal society, have to be obedient to males and cannot control their own destiny. The patriarchal ideology has left a double imprint on the spirit and soul of women. "Women have experienced a common child stage and then experienced her own stage to become herself. The nature in her situation has little meaning 


\section{IRA-International Journal of Education $\Xi^{\circ}$ Multidisciplinary Studies}

because she can only exist but not to design. ${ }^{[9] 212}$. Women could only passively accept the value of the patriarchal system and suppress their own instincts and emotions, losing individualism and identity.

To some extent, the tragedy of No Name Woman has totally resulted from the oppression of patriarchy. The image of a male is the source of all the rules of constraint. That's to say, women are an accessory of their husbands. From the villagers' standpoints, only women ought to take responsibility for the adultery, which has nothing to do with men. It is a self-evident fact that the treatment to male and female is not fair at all. For No Name Woman, she has been physically and mentally injured by the man who raped her, the villagers, and her family. Under the oppression of patriarchy, No Name Woman has no choice but to endure silently the condemnation and the unfair treatment given by society. So death is probably the best end for her.

In addition, Moon Orchid is another victim of the patriarchal society. The relationship between Moon Orchid and her husband is abnormal and distorted. The influence of the traditional culture makes her get weaker and weaker. Ridiculously, it is at the expense of the rest of her life to accept unfair treatment. She dares not get her husband back, let alone to defend her basic rights as a wife. What surprises us most is that her husband could build a new family in America, but he isn't punished by the law. It is obvious that it's her husband's fault in that he betrays and abandons her wife. Moon Orchid is just like a toy manipulated by her husband. Psychological trauma forces her to walk towards the edge of despair step by step.

\subsection{Cultural Differences}

Compared with the traditional Chinese culture, American culture advocates individualism, emphasizing the importance of the individual and independence. Americans are proud of their unique personal quality. They are usually independent of others or even don't need their parents' help. While Chinese culture upholds Confucian collectivism culture, which values family, benevolence, and class level. Chinese parents often intervene in the development of their children. Besides, American culture could be considered as the culture of freedom and self-expression. Americans asserted that everyone has the freedom to express their own ideas and to do whatever they like. By contrast, Chinese are required to obey rules and to express themselves implicitly. Moreover, American individualism culture lays stress on the equality among people. Regardless of their gender and race, everyone is entitled to equal rights and dignity. They are greatly influenced by the "American Dream"- Life should be better, richer, and fuller for everyone, with opportunity for each according to the ability or achievement regardless of social class or circumstances of birth. Through hard work, one can achieve a better life for oneself. Conversely, Chinese traditional culture places special emphasis on hierarchy and rank. A woman must be inferior to men and children must obey the parents' orders. In short, there are scores of difference between Chinese and American culture.

Based on the all-round analysis, the readers could easily figure out that culture contributes mightily to Chinese females' trauma. "As a cultural process, trauma is mediated through various forms of representation and linked to the reformation of collective identity and the reworking of collective memory." ${ }^{,[10] 132}$. Originally, Moon Orchid lived a happy and peaceful life in China. After coming to America, she is incompatible with the mainstream of western culture. As the Chinese traditional culture 
has already deeply been rooted in Chinese American immigrants, it is quite difficult for them to get accustomed to the American culture. Because Moon Orchid cannot speak English, she couldn't pour out her pains and sorrow to anyone. And she worries that she couldn't make a living on her own for she couldn't find a suitable job in this strange country. Faced with the external stimulation, she is not able to develop an effective defense mechanism. Therefore, Moon Orchid's trauma is nearly disastrous. In addition, little Maxine and other Chinese American girls use silence to isolate themselves from the outside world. In such a different situation, they desperately lack a sense of security, which intensifies the feeling of fear and depression. Culture shock is a big barrier that constrains them from blending in with the surroundings and starting a new life. As we can imagine, cultural conflict brings enormous trauma to Chinese American females. And it is really difficult for them to look for their new identity.

\subsection{Racial Discrimination}

Race is a complicated word. According to Omi and Howard Winant, "Race is a concept signifying social conflicts and interests by referring to different types of human bodies." (Wikipedia). Racial discrimination is a kind of discrimination against an individual on the basis of their race. As America is a country consisting of different races, it is a documented fact that some white people are born with superiority and prejudice. For Chinese American immigrants, perhaps, the trauma caused by racial discrimination is not as obvious as black people. More or less, the unfair treatment and racial discrimination are not reflected in the skin color like the black, but the mental trauma is indeed fatal for Chinese American females. The Chinese American immigrants are called "marginalized men" because of the renunciation of self-ethnic culture and the loss of self-identity. This group of people could not have the true feeling of pride, so they are very fragile and sensitive, making them more vulnerable.

In this novel, Brave Orchid spares no effort to become a successful doctor in China. She is clever and intelligent enough to have acquired a medical practitioner's certificate. Because of her excellent medical skills, she is very respectable in China. However, her qualifications are not recognized in America. And she cannot speak English, so she has no choice but to do laundry. "I have no idea how much I have fallen coming to America." ${ }^{[3] 77}$. From a powerful and professional doctor to a common and inferior woman, the change in social status suggests that it is impossible for Chinese American females to attain equal rights with the local people. Racial discrimination leads her to complain about her situation, which intensifies her physical and mental trauma.

As the second-generation of Chinese American immigrants, Maxine's growth is full of fear and inferiority. Even though she was born in America, she could not find her "home" at all. Because she couldn't speak English fluently, she is always laughed by her classmates. "After a traumatic event, we can also become 'numb' and shut down our feelings and try to avoid the situation that might cause us to remember the trauma." ${ }^{[11] 128}$. A school is a traumatic place for Maxine, she is reluctant to re-experience the trauma again. Racial discrimination forces her to have the desire to escape from school. Actually, Maxine's aphasia is a way of keeping away from American students. Due to the sense of guilt, Chinese students prefer keeping silent. So it is necessary for Chinese American females to rebuild their identity by overcoming the trauma brought by racial discrimination. 


\section{The Recovery of Chinese American females' Trauma}

\subsection{Pursuit of Dream for Brave Orchid}

Brave Orchid is a brave, tough, and ambitious woman from a little village. After her husband left for America, she didn't rely on her husband's financial support like other women in the village. "She decides to use the money for becoming a doctor." ${ }^{[3] 60}$. We can imagine how painful she was when her two children have died two years before. But she wasn't defeated by the big changes. On the contrary, she is brave and strong enough to work through the trauma and look forward to the future with hope.

Everyone has the right to pursue his or her dream. Being a doctor is Brave Orchid's dream. So Brave Orchid forgets the pain and sorrow and embarks on a new journey to pursue her dream. She becomes a student of The Hackett Medical School. In college, she is outstanding in that she is brilliant and hard-working. With an exquisite knowledge of medical technology and great personalities, she returns to her village and become a distinguished doctor. As the victim of the oppression imposed by a feudal social system and culture conflicts like No Name Woman and Moon Orchid, Brave Orchid has a strong will and great courage to face the sufferings and difficulties. She takes a positive and unyielding attitude to the hard life. Furthermore, she dares to make resistance to inequality and prejudice. Most important of all, she makes great determination to make a change and pursue her dream even if it is not a golden age for study anymore. At last, Brave Orchid gets rid of the shadow of the past and greets the new life with confidence.

\subsection{Striving for Family Union for Moon Orchid}

The character of Moon Orchid has been reflected through Moon Orchid's inner activities when she just arrived in America. "It surprised Brave Orchid that after thirty years she could still get annoyed at her sister's silliness." [3]106. Brave Orchid is disappointed about the vulnerable and cowardly sister. Maybe Moon Orchid is still satisfied with the situation in which she could enjoy life with wealth and comfort depending on the money sent by her husband; maybe she still holds a ray of hope that her husband will come back to reunite with her; maybe she still takes it for granted that her husband could be forgiven as long as he still feeds her.

However, Brave Orchid doesn't think so. Her view is consistent with the following principle: "Being a wife or mother will not necessarily make a woman weak, submissive or passive. Rather, it is the patriarchal hierarchy that makes women that way." ${ }^{,[2] 37}$. Brave Orchid tries her best to bring her sister to America and helps her to win over her fundamental rights as a female. Whenever Moon Orchid hesitates, Brave Orchid always encourages her to strive for justice and challenge reality. Although the result is not as perfect as she expects, the spirit of fighting for the interests of Moon Orchid inspires many Chinese American females including Maxine and her sister. For a while, Moon Orchid is curious about the new things in America and full of vigor and pride for her progress.

\subsection{The Change of Maxine}

Under the influence of traditional Chinese values - people prefer boys to girls, Maxine could not find a sense of safety in her family or Chinatown. A girl is viewed as something shameful. "I mind that 


\section{IRA-International Journal of Education $\Xi^{\circ}$ Multidisciplinary Studies}

the emigrant villagers shook their heads at my sister and me 'One girl and another girl', they said, and made our parents ashamed to take us out together." [3]46. Maxine hopes to become a boy-she imitates boys' behavior, even makes mistakes and does bad things like boys. When she hears someone say "Feeding girls are feeding cowbirds" or something like this, she would become angry and even fight with others. But no matter how she tries, she could neither change her gender nor break the customs. In order to avoid discrimination and prejudice, she tries her best to leave her family as far as possible, which enable her to relieve the psychological symptom of trauma.

Besides, Maxine threatens other Chinese American girls to speak English bravely. "I hated the younger sister, the quiet one. I hated when she was the last chosen for her team and I, the last chosen for my team." ${ }^{[3] 153}$. Maxine hates the little girl for she always keeps silent. She could find her shadow in the little girl. On one hand, Maxine wants to help the silent girl to articulate; on the other hand, she hopes to articulate. This silent girl reflects a part of her own experience - she is always repressed by the trauma. Finally, Maxine gets rid of the shadow of silence and the pain of trauma by helping the girl. Maxine has one kind of temperament which is distinctive from other Chinese American females-she has the determination to face trauma and break the shackles. It is Maxine's change that makes her recover from psychological trauma.

\section{Conclusion}

In face of the oppression of patriarchy, culture conflict, and racial discrimination, Chinese American females choose different attitudes towards the intractable situation. Whether it is women who are relatively weak in character or Chinese woman warrior who are determined and courageous, they must face numerous challenges and experience different levels of trauma in the process of their growth.

The trauma of females has always been a concern of many scholars. Chinese American females have been struggling with multiple traumas caused by gender and culture. Traumatic memory is transmitted from generation to generation, lingering in the hearts of these women. The Woman Warrior, Maxine Hong Kingston's most successful work, provides a good opportunity for Chinese American females to tell their traumatic experience so that most readers could listen to them. Through personal and collective memory, they could bravely confront and understand trauma. Most important of all, it is in this way that they could get out of the shadow of trauma, thus finding their identity and statue again.

This thesis develops a full analysis of The Woman Warrior in the light of trauma theory. We have learned about Chinese American females' traumatic experience, the causes of their trauma, and how they recover from their psychological trauma. All of us are bound to face various difficulties and frustration, but we should have the courage and determination to sail through the unusual ups and downs, thus attaining our ultimate goal of life. At last, the author of this thesis hopes all females could overcome all sorts of trauma and become the true women warriors in our colorful life.

\section{References}

[1]. Lin Jian. The Iron Curtain of Language: Maxine Hong Kingston and American Orientalism, Shanghai: Fudan University press, 2007.

[2]. Anne Whitehead. Trauma Fiction [M]. Edinbursh: Edinburgh University Press, 2004. 
[3]. Kingston, Maxine Hong. “The Woman Warrior” New York: Vintage Books, 1976.

[4]. Jiang Xiaoqi. A Study on Trauma and Recovery in Kingston's The Woman Warrior from the Perspective of Trauma Theory [D]. Shenyang Normal University, 2014.

[5]. Cheng Aimin, A Study of Chinese American Literature [M]. Beijing: Peking University Press, 2004.

[6]. Vickrony, Laurine. Trauma and Survival in Contemporary Fiction. Clarlottesville: University of Virginia Press, 2002

[7]. Liu Fenghui. An Analysis of Desire under the Elms from the Perspective of Trauma Theory [D]. Harbin Normal University, 2015.

[8]. Herman, Judith. MP. Trauma and Recovery [M]. New York: Basic Books, 1992.

[9]. Simon de Beauvoir. The Second Sex [M]. Translated by Zheng Kelu. Shanghai Translation Publishing House, 2011.

[10].Ron, Eyerman. Culture Trauma [M]. Cambridge: Cambridge University Press, 2001.

[11].Caroline, Garland. Understanding Trauma: A psycholanalytical Approach [M]. London: Duch Worth, 1998.

[12]. Wang, Jianhui. Gender \& Racial Politics in the Works of Chinese American Women Writers[M] China Ocean University Press, 2011. 